\title{
Response of Quinoa (Chenopodium quinoa Willd) Plant to Nitrogen Fertilization and Irrigation by Saline Water
}

\author{
Amal H. Mahmoud ${ }^{1 *}$, Sobhi Sallam ${ }^{2}$
}

\begin{abstract}
The response of quinoa (Chenopodium quinoa Willd.) grown under salinity stress of irrigation water to nitrogen fertilization for improving yield production and quality was investigated. In plots experiment, application of 0 (N0), 14.28 (N1) and 28.56 (N2) $\mathrm{g} \mathrm{N} \mathrm{m}^{-2}$ as ammonium sulfate to quinoa (cultivar Regalona) sown in clay textured soil and irrigated by water of $0.65,10$ and $20 \mathrm{dS}$ $\mathrm{m}^{-1}$ was studied. The results showed that application of nitrogen improved both biomass and seed yield. Nitrogen fertilization at rates of 14.28 and $28.56 \mathrm{~g} \mathrm{~m}^{-2}$ increased the yield of biomass by about 33.5 and $60 \%$ more than the control under fresh and $10 \mathrm{dS} \mathrm{m}^{-1}$ saline water irrigation. Under irrigation with $20 \mathrm{dS} \mathbf{m}^{-1}, \mathbf{N}$ application by corresponded rates increased the biomass by 57 and $100 \%$, respectively. Similar results were obtained with seed yield. Results of $\mathrm{N}$ content in seed and hay indicated that, under non-saline conditions, $N$ content increased by 7.9 and $39.7 \%$ in hay and 15.9 and $36.8 \%$ in seeds over the control when the plant fertilized by 14.28 and $28.56 \mathrm{~g} \mathrm{~N} \mathrm{~m}^{-2}$, respectively. Seed-N decreased by about $17.0,5.2$ and $8.0 \%$ in the plants irrigated with water of $10 \mathrm{dS} \mathrm{m}^{-1}$ and treated by $\mathrm{N0}, \mathrm{N} 1$ and $\mathrm{N} 2$, respectively, whereas irrigation with 20 dS $\mathrm{m}^{-1}$ water decreased seed-N by $26.4,10.4$ and $17.7 \%$ in plants fertilized by N0, N1 and N2 respectively. Under nonsaline conditions, nitrogen utilization efficiency (NUtE) decreased from 55.1 to 47.5 and $40.3 \mathrm{~kg}$ seed $\mathrm{kg}^{-1} \mathrm{~N}$ in plants treated byN0, N1and N2. Similar trends were observed in the plants irrigated by higher levels of water salinity. The results indicated that quinoa hay yield responded to $\mathrm{N}$ application more than seed yield response. In N0-treated plants, NUtE increased from 55.1 to 66.2 and $74.7 \mathrm{~kg} \mathrm{seed} / \mathrm{kg} \mathrm{N}$ in plants irrigated by water of $0.65,10$ and $20 \mathrm{dS} \mathrm{m}^{-1}$, respectively. $\mathrm{N}$ fertilization with $\mathrm{N} 1$ and $\mathrm{N} 2$ did not influence $\mathrm{Na}$ and improved $\mathrm{K}$ content in the hay of plants irrigated by saline water $\left(10\right.$ and $\left.20 \mathrm{dS} \mathrm{m}^{-1}\right)$. The use of quinoa hay as ruminant feed was supported by the results of both organic material content and high levels of crude protein as comparing to clover hay. However, the low percent of ether extract and higher percents of ADF and NDF lowered its quality. Therefore, it could be strong feed supplement for ruminants.
\end{abstract}

Keywords: quinoa, saline water, forage, ruminants, nitrogen utilization efficiency.

${ }^{1}$ Department of Soil Salinity and Alkalinity Research, Institute of Soil, Water and Environment Research, Agricultural Research Center, Alexandria, Egypt. E.mail: amal_matter117@yahoo.com.

${ }^{2}$ Department of Animal Production, Faculty of Agriculture, Alexandria University, Alexandria, Egypt.

Received May 12, 2017, Accepted June 29, 2017

\section{INTRODUCTION}

Marginal land in Mediterranean region represents a significant area and the climate changes impacts lead to further land degradation and water scarcity in such arid and semi arid environments (Tomaz et al., 2013; Karamesouti et al., 2015). Some features of degradation can be seen due to soil salinization and drought (Abdel Kawy and Ali, 2012), therefore, the agro-ecosystems adaptation studies have been increased (Hiernaux et al., 2016; Tokatlidis, 2013; El-Ramady et al., 2013; RomoLeon and van Leeuwen, 2016) particularly towards introducing salt and drought tolerant crops as alternatives for traditional grain and fodder crops (Ahmed et al., 2016; Malhotra and Chhabra, 2013; Galvani, 2007). Quinoa (Chenopodium quinoa Willd) has garnered much attention in recent years because it is highly tolerant to soil salinity and drought (Wu et al., 2016; González et al., 2015). Quinoa is known as seed (pseudo grain) crop and classified within the super foods for its high content in protein and high content in lysine, which is considered the first limiting essential amino acid in cereals (Arendt and Zannini, 2013; Livingston, 2013). In view of its exceptional nutritional quality and ability to grow under marginal environments, the Food and Agriculture Organization of the United Nations (FAO) has identified quinoa as one of the crops that will play an important role in ensuring future food security and designated the year 2013 as the "Year of Quinoa" (Bazile et al., 2015). In previous study, Mahmoud (2017) showed that quinoa was successfully grown under the winter season of south Mediterranean climate between Med December to the last third of January at Northwest Nile delta, Egypt. Other studies confirmed the success of quinoa production at South Sinai (Shams, 2011) and Giza, Ismailia and Wadi El-Natroun, Egypt (Shams, 2015).

Under abiotic stress conditions (e.g., high soil and/or water salinity and alkalinity and drought), quinoa, as a facultative halophyte (Ruiz et al., 2014) needs to pay attention to fertilization. N, P and $\mathrm{K}$, fertilization play significant role in crop growth and production improvement where Mujica et al. (2001) stated that quinoa has high requirements for nitrogen $(\mathrm{N})$ and 
calcium $(\mathrm{Ca})$, moderate for phosphorous $(\mathrm{P})$, and minimal for potassium $(\mathrm{K})$ and respond strongly to $\mathrm{N}$ fertilization (Schulte auf'm Erley et al.,2005). Quinoa as a halophyte is adapted to harsh environments with highly saline soil and its seed quality affected not only by salinity level but also by the type of prevalent salts (Wu et al., 2016). In several countries, quinoa plant not only is used as super food for humankind but also used as forage for livestock and poultry. In South American region, the grain of quinoa is used primarily for human food and the plant stocks used for animal feed (Rosero et al., 2010; Kubelkov et al., 2013; Robinson et al., $2013 \mathrm{a}$ and b). As feed, quinoa seeds were beneficiary diet when introduced to broilers (Jacobsen et al., 1997). Also, cooked quinoa was introduced as protein supplement to pigs, cattle and chicks (Scanlin and Lewis, 2017).

Under the arid and semi arid conditions of Mediterranean region, quinoa species grow well but there are no detailed studies on its response to nitrogen fertilizer rates when the plant grows under stressed conditions such as high salinity of soil and/or irrigation water. Therefore, the objectives of the current study focused on the influence of $\mathrm{N}$ application on yield response of quinoa irrigated with saline water and on the quality of quinoa hay as forage for livestock.

\section{MATERIALS AND METHODS}

Plot experiment was conducted to determine the effects of nitrogen fertilization and saline water irrigation on growth, yield and quality of quinoa crop (Chenopodium quinoa Willd.). The agronomic performance and nitrogen uptake by quinoa were evaluated in order to define substitutes to local winter forages feeding of ruminants and sheep. The experiment was laid out in a randomized complete block design with four replicates in plots $(120 \mathrm{~cm} \times 70 \mathrm{~cm})$ containing clay soils. The soil properties are listed in Table (1). It was carried out at Soil Salinity and Alkalinity Research Laboratory, Alexandria, Egypt (GPS: "26.56'29 56 east and " $02.11^{\prime} 31^{\circ} 13$ north). Fertilizers at rates of 16.7 and $14.3 \mathrm{~g} \mathrm{P}_{2} \mathrm{O}_{5}$ and $\mathrm{K}_{2} \mathrm{O}$ per square meter were applied in the forms of single superphosphate $\left(\mathrm{P}_{2} \mathrm{O}_{5} 15.5 \%\right)$ and potassium sulfate $\left(\mathrm{K}_{2} \mathrm{O} 50 \%\right)$, respectively. Seeds of quinoa cultivar of Regalona were sown in two rows per plot (distance between rows is $50 \mathrm{~cm}$ and between plants $30 \mathrm{~cm}$ ) by putting 3 seeds in each hole in the upper $3 \mathrm{~cm}$ soil surface. The treatments are containing three nitrogen fertilizer rates $(0,14.28$ and $28.56 \mathrm{~g} \mathrm{~N}$ per square meter in the form of ammonium sulfate (N 21\%) and denoted as N0, N1 and N2, respectively) and three levels of water salinity (fresh water, $\mathrm{EC}=0.65 \mathrm{dS} \mathrm{m}^{-1}$, saline water, $\mathrm{EC}=10$ and $20 \mathrm{dS} \mathrm{m}^{-1}$ by using sodium chloride salt). After 21days from sowing date
(December 25, 2015), one third of nitrogen fertilizer was applied and the two other thirds were applied after 45 and 65 days of plant sowing. The quinoa plants were irrigated with the three levels of water salinity. After 128-135 days from sowing, the above-ground plant biomass was harvested from each plot and the dry weights were recorded. The seeds then were separated and their weights were recorded. The harvest index (HI) was calculated according to the following equation:

$$
\text { Harvest Index }(\mathrm{HI})=\frac{\text { seed yield }\left(\mathrm{gm}^{-2}\right)}{\text { above ground blomass yield }\left(\mathrm{gm}^{-2}\right)}
$$

\section{Nitrogen in seeds and hay}

The quinoa seeds were crushed by mortar then sieved through $0.5-\mathrm{mm}$ polyethylene sieve. Also, the airdried plant hay was crushed and sieved as mentioned above. The amounts of total nitrogen in seeds and hay of quinoa plants were determined using kjeldahl procedure (Jones and Case, 1990) where $0.5 \mathrm{~g}$ seed or hay powder were transferred into Kjeldahl's digestion tubes, $5.0 \mathrm{~g}$ of digestion mixture (100:1:100 $\mathrm{CuSO}_{4} \cdot 5 \mathrm{H}_{2} \mathrm{O}: \mathrm{Se}: \mathrm{K}_{2} \mathrm{SO}_{4}$, respectively) was added to the plant tissue then $10 \mathrm{~mL}$ of concentrated $\mathrm{H}_{2} \mathrm{SO}_{4}$ was added. Kjeldahl tubes were transferred into the digester (Tecator Digestion system 20 , Sweden) and the digestion heat reached to $410{ }^{\circ} \mathrm{C}$ and settled to 60 minutes. After cooling, the tubes were transferred to Kjeldahl distillation unit (Foss tecator 2100 Kjeltec, Sweden) for determiner total $\mathrm{N}$ as described by Jones and Case (1990). Nitrogen

\begin{tabular}{|c|c|}
\hline Property & Value \\
\hline \multicolumn{2}{|l|}{ Particle size distribution: } \\
\hline Sand $(\%)$ & 6.21 \\
\hline Silt $(\%)$ & 18.20 \\
\hline Clay $(\%)$ & 75.59 \\
\hline Soil texture: & Clay \\
\hline Total carbonate $(\%)$ & 3.98 \\
\hline Cation exchange capacity (CEC, $\left.\mathrm{cmol} \mathrm{kg}^{-1}\right)$ & 55.61 \\
\hline Electrical Conductivity $\left(\mathrm{EC}, \mathrm{dS} \mathrm{m}^{-1}\right)$ & 3.37 \\
\hline $\mathrm{pH}$ & 7.42 \\
\hline \multicolumn{2}{|l|}{ Water soluble cations (meq L ${ }^{-1}$ ) } \\
\hline $\mathrm{Ca}^{2+}$ & 11.40 \\
\hline $\mathrm{Mg}^{2+}$ & 8.60 \\
\hline $\mathrm{Na}^{+}$ & 14.00 \\
\hline $\mathrm{K}^{+}$ & 0.35 \\
\hline SAR & 4.44 \\
\hline \multicolumn{2}{|l|}{ Water soluble anions (meq L $\left.{ }^{-1}\right)$} \\
\hline $\mathrm{Cl}^{-}$ & 18.50 \\
\hline $\mathrm{HCO}_{3}^{-}$ & 3.55 \\
\hline $\mathrm{SO}_{4}^{2-}$ & 11.90 \\
\hline
\end{tabular}

Table1. The main physical and chemical properties of the used soil in the study 
Utilization Efficiency (NUtE) was calculated according to the following equation:

$$
N U t E=\frac{\text { seed yield }\left(\mathrm{gm}^{-2}\right)}{\text { seed Nuptake }\left(\mathrm{gm}^{-2}\right)}
$$

\section{Sodium and potassium in hay}

Sodium and potassium contents of quinoa hay were determined using the dry-ashing procedure (Jones and Case, 1990) where 0.5 gram of $0.5-\mathrm{cm}$ ground dried hay was transferred into porcelain crucible and heated to 550 ${ }^{\circ} \mathrm{C}$ in a muffle furnace for 6 hours. After cooling, the ash was dissolved in $10 \mathrm{~mL}$ dilute acids mixture $(600 \mathrm{~mL}$ distilled water:300 mL $\mathrm{HCl}: 100 \mathrm{~mL} \quad \mathrm{HNO}_{3}$ ) and transferred into $250-\mathrm{mL}$ volumetric flasks then the volume of $250 \mathrm{~mL}$ was completed by distilled water. Concentrations of $\mathrm{Na}$ and $\mathrm{K}$ were measured using flame photometer (Jenway model CM6 3LB, UK).

\section{Biomass compositional analysis}

The dry plant hay of quinoa was milled by hand to fine powder using porcelain mill then passed through $0.5-\mathrm{mm}$ sieve and kept in plastic bottles for analysis. Organic matter $(\mathrm{OM})$, crude protein $(\mathrm{CP})$, ether extract (EE), acid detergent fiber (ADF), neutral detergent fiber (NDF) and acid detergent lignin (ADL) were analyzed according to procedures of AOAC (1990) and Van Soest et al. (1991). The hemicelluloses (HCEL) content was obtained by subtracting ADF from NDF and the cellulose (CEL) content by subtracting ADL from ADF.

\section{RERSULTS AND DISCUSSION}

\section{Effect of $\mathbf{N}$ application on Yield:}

Table 2 showed that, without nitrogen fertilization, about 0.95 and $19.4 \%$ of quinoa biomass decreased as a result of irrigation with water of 10 and $20 \mathrm{dS} \mathrm{m}$, respectively, as compared to those irrigated with fresh water. Nitrogen fertilization at rates of 14.28 and 28.56 $\mathrm{g} \mathrm{m}^{-2}$ increased the yield of biomass by about 33.5 and
$60 \%$ more than the control under fresh and $10 \mathrm{dS} \mathrm{m}^{-1}$ saline water irrigation. Under irrigation with $20 \mathrm{dS} \mathrm{m}^{-1}$, $\mathrm{N}$ application by corresponded rates increased the biomass by 57 and $100 \%$, respectively. Similar results were obtained with respect to the seed yield where the application of nitrogen significantly increased the yield under non-saline and saline conditions of irrigation water (Table 2). The relative increases in biomass and seed yield are illustrated in Fig. (1).The application of nitrogen improved both biomass and seed yield which agreed with Razzaghi et al. (2012) and Schulte auf'm Erley et al. (2005). Under high salinity conditions (20 $\mathrm{dS} \mathrm{m^{-1 }}$ ), N application rate of $\mathrm{N} 2$ had great influence on growth improvement of Regalona quinoa as compared with its influence under non-saline conditions (Fig. 1).

No change in the harvest index (HI) was observed according to raising the $\mathrm{N}$ application rates with fresh or $10 \mathrm{dS} \mathrm{m}{ }^{-1}$ irrigation water. However, an obvious reduction in $\mathrm{HI}$ was induced for the plants irrigated with $20 \mathrm{dS} \mathrm{m}^{-1}$ saline water (Table 2). Under non-saline conditions, Schulte auf'm Erley et al. (2005) found that HI of some quinoa cultivars (Cochabamba) was enhanced by $\mathrm{N}$ fertilization. Szilagyi and Jornsgard (2014) reported that the high and low harvest index values are related to the early and late maturity of quinoa genotypes where they found that early maturity genotypes recorded a higher harvest index than late maturity genotypes. Also, low values of harvest index for late and high values for early maturity genotypes supported similar findings by Spehar and de Barros Santos (2005). It seems that improvement of HI of quinoa seed yield is related to various factors rather than $\mathrm{N}$ fertilization such as genotypic and abiotic variations.

\section{Influence of $\mathbf{N}$ application on $\mathbf{N}$ content}

As shown in Table (2), nitrogen content in both seed and hay of Regalona quinoa cultivar increased as $\mathrm{N}$ application rate increased.

Table 2. Mean values (followed by STDEV values) of Biomass and seed yield, harvest index, nitrogen content and nitrogen utilization efficiency of quinoa plant (cultivar Regalona) as influenced by nitrogen fertilization rate and irrigation with saline water

\begin{tabular}{|c|c|c|c|c|c|c|c|}
\hline \multirow[b]{2}{*}{$\begin{array}{l}\text { N rate } \\
\left(\mathrm{g} \mathrm{m}^{-2}\right)\end{array}$} & \multirow{2}{*}{$\begin{array}{c}\text { Water } \\
\text { salinity } \\
\left(\mathbf{E C}, \mathbf{d S ~ m}^{-1}\right)\end{array}$} & \multirow[b]{2}{*}{$\begin{array}{l}\text { Dry Biomass } \\
\qquad\left(\mathrm{g} \mathrm{m}^{-2}\right)\end{array}$} & \multirow[b]{2}{*}{$\begin{array}{l}\text { seed yield } \\
\left(\mathrm{g} \mathrm{m}^{-2}\right)\end{array}$} & \multirow[b]{2}{*}{ HI } & \multicolumn{2}{|c|}{$\mathrm{N}$ in plant $(\%)$} & \multirow[b]{2}{*}{$\begin{array}{c}\text { NUtE }\left(k^{-1}\right. \\
\left.\mathrm{kg}^{-1} \mathbf{N}\right)\end{array}$} \\
\hline & & & & & Hay & seed & \\
\hline \multirow[t]{3}{*}{0} & 0.65 & $923.48 \pm 23.24$ & $418.08 \pm 9.35$ & $0.45 \pm 0.01$ & $2.14 \pm 0.07$ & $1.82 \pm 0.02$ & $55.10 \pm 0.72$ \\
\hline & 10.00 & $914.72 \pm 37.54$ & $394.47 \pm 7.41$ & $0.43 \pm 0.02$ & $2.23 \pm 0.05$ & $1.51 \pm 0.03$ & $66.24 \pm 1.28$ \\
\hline & 20.00 & $744.50 \pm 85.59$ & 330.13 & $0.44 \pm 0.06$ & $1.97 \pm 0.05$ & $1.34 \pm 0.03$ & $74.66 \pm 1.88$ \\
\hline \multirow[t]{3}{*}{14.28} & 0.65 & $1232.50 \pm 36.04$ & $574.31 \pm 9.02$ & $0.47 \pm 0.02$ & $2.31+0.03$ & $2.11 \pm 0.09$ & $47.47 \pm 2.12$ \\
\hline & 10.00 & $1220.97 \pm 24.71$ & $542.13 \pm 22.84$ & $0.44 \pm 0.02$ & $2.32 \pm 0.06$ & $2.00 \pm 0.01$ & $50.00 \pm 0.20$ \\
\hline & 20.00 & $1170.05 \pm 47.33$ & $448.34 \pm 38.71$ & $0.38 \pm 0.04$ & $2.77 \pm 0.08$ & $1.89 \pm 0.03$ & $52.99 \pm 0.93$ \\
\hline \multirow[t]{3}{*}{28.56} & 0.65 & $1478.82 \pm 60.04$ & $640.64 \pm 38.11$ & $0.44 \pm 0.04$ & $2.99 \pm 0.06$ & $2.49 \pm 0.06$ & $40.26 \pm 1.04$ \\
\hline & 10.00 & $1471.33 \pm 63.03$ & $680.70 \pm 27.99$ & $0.46 \pm 0.02$ & $2.97 \pm 0.06$ & $2.29 \pm 0.14$ & $43.89 \pm 2.75$ \\
\hline & 20.00 & $1491.96 \pm 93.56$ & $606.92 \pm 6.46$ & $0.41 \pm 0.03$ & $2.38 \pm 0.09$ & $2.05 \pm 0.04$ & $48.73 \pm 0.91$ \\
\hline
\end{tabular}



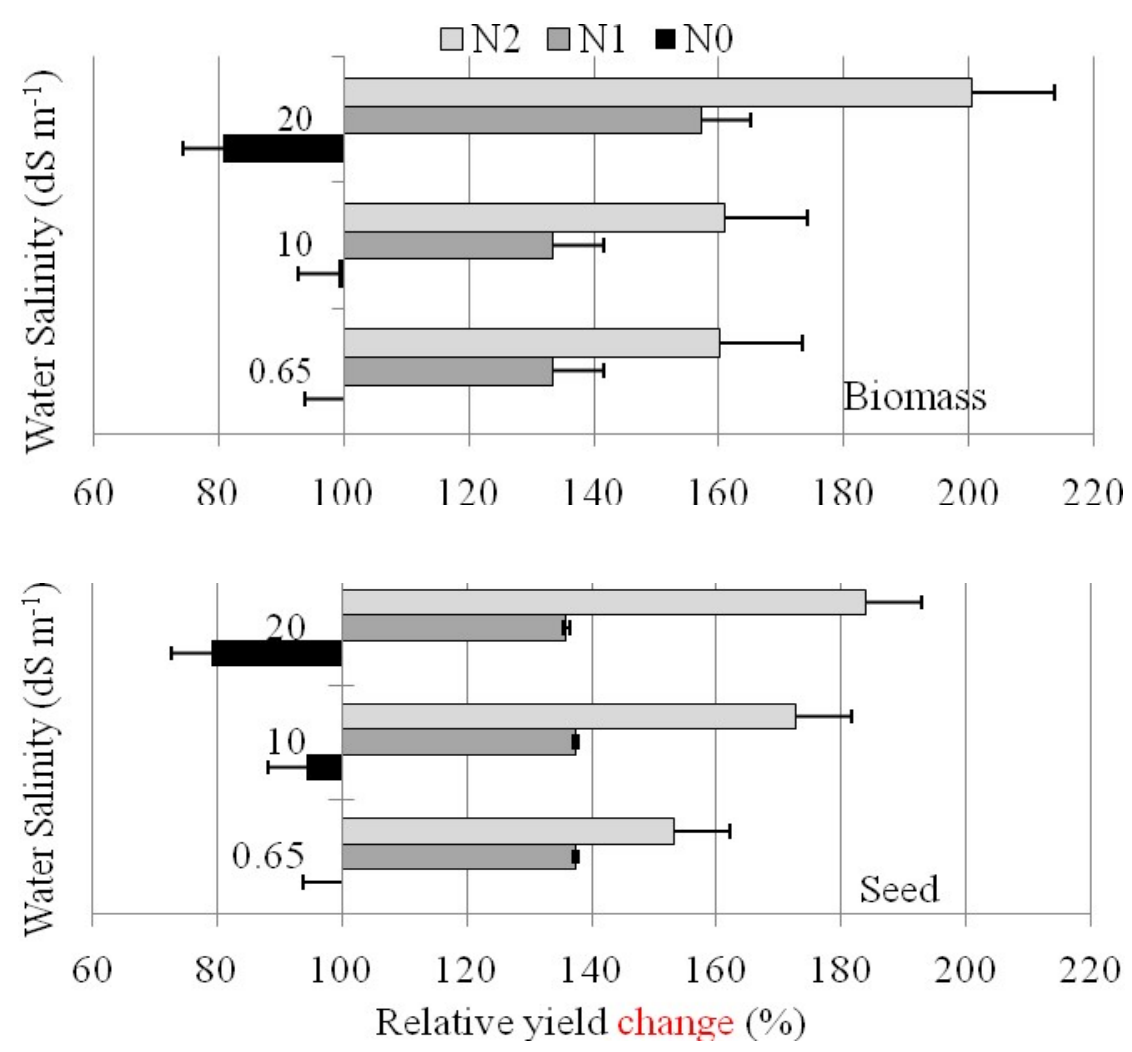

Fig.1. The relative yield of quinoa as results of nitrogen application rate under different levels of irrigation water salinity

On the other hand, the influence of water salinity on $\mathrm{N}$ content in plant hay slightly changed without significant trend whereas, in the seed, $\mathrm{N}$ content decreased as water salinity increased. Seed-N decreased by $17.0,5.2$ and $8.0 \%$ in the plants irrigated by water of $10 \mathrm{dS} \mathrm{m}^{-1}$ and treated by N0, N1 and N2, respectively, whereas irrigation with $20 \mathrm{dS} \mathrm{m}^{-1}$ water decreased seed-N by $26.4,10.4$ and $17.7 \%$ in plants fertilized by N0, N1 and $\mathrm{N} 2$ respectively. These results show the importance of $\mathrm{N}$ fertilization of quinoa grown under salinity stress to maintain adequate or high level of seed protein. The importance of $\mathrm{N}$ application can be seen in the grown quinoa under non-saline conditions where $\mathrm{N}$ contents in both hay and seed increased by 7.9 and by $39.7 \%$ in hay and 15.9 and $36.8 \%$ in seeds over the control when the plants are fertilized by 14.28 and $28.56 \mathrm{~g} \mathrm{~N} \mathrm{~m}^{-2}$, respectively (Table 2). The relative changes in $\mathrm{N}$ content in both seeds and hay of quinoa plant as results of $\mathrm{N}$ application rate and water salinity are illustrated in Fig (2).

The calculated values of nitrogen utilization efficiency (Table 2) showed that under non-saline water conditions, NUtE decreased as applied $\mathrm{N}$ rate increased, since NUtE values decreased from 55.1 to 47.5 and 40.3 $\mathrm{kg}$ seed $\mathrm{kg}^{-1} \mathrm{~N}$ in plants treated by $0,14.28$ and $28.56 \mathrm{~g}$
$\mathrm{N} \mathrm{m}^{-2}$. As demonstrated in Table (2), similar trends were observed in the plants irrigated by higher levels of water salinity $\left(\mathrm{EC}=10\right.$ and $\left.20 \mathrm{dS} \mathrm{m}^{-1}\right)$. These results indicated that quinoa hay yield responded to $\mathrm{N}$ application more than seed yield. Under saline conditions and zero $\mathrm{N}$ application, soil $\mathrm{N}$ utilization by quinoa increased as salinity of water increased. NUtE values increased from 55.1 to 66.2 and $74.7 \mathrm{~kg}$ seed $\mathrm{kg}^{-1} \mathrm{~N}$ in plants irrigated by water of $0.65,10$ and $20 \mathrm{dS} \mathrm{m}^{-1}$, respectively (Table 2 ). This trend could be related to the genotype because some other studies found that quinoa cultivar Cochabamba had a higher NUtE than Faro and NUtE was not affected by applied $\mathrm{N}$ rate (Schulte auf'm Erley et al., 2005). In another study, the variations in NUtE were attributed to soil texture class where Razzaghi et al (2012) found that the NUtE by cultivar of quinoa (cv. Titicaca) grown on sandy soil was significantly higher than that of sandy loam and sandy clay loam soils.

\section{Influence of $\mathrm{N}$ Application on $\mathrm{Na}$ and $\mathrm{K}$ uptake:}

Figure 3 represents the relationship between irrigation water salinity and $\mathrm{Na}$ and $\mathrm{K}$ content in the hay of quinoa plant as a result of various rates of applied $\mathrm{N}$ fertilizer. Without $\mathrm{N}$ application, $\mathrm{Na}$ content in quinoa hay increased as water salinity increased and vice versa with respect to $\mathrm{K}$ content. The study of Mahmoud 
(2017) confirmed this trend of $\mathrm{Na}$ and $\mathrm{K}$ in Regalona cultivar. Application of nitrogen fertilizer at a rate of 14.29 and $28.58 \mathrm{~g} \mathrm{~m}^{-2}$ did not influence $\mathrm{Na}$ content in plant hay and improved $\mathrm{K}$ content with irrigation by saline water $\left(10\right.$ and $\left.20 \mathrm{dS} \mathrm{m}^{-1}\right)$. In the plants received 14.29 and $28.58 \mathrm{~g} \mathrm{~N} \mathrm{~m}^{-2}, \mathrm{~K}$ content in quinoa hay increased by about 52.5 and $26.1 \%$ in the plant hay irrigated with $10 \mathrm{dS} \mathrm{m}^{-1}$ water and by about 65.8 and $83.1 \%$ in those irrigated with $20 \mathrm{dS} \mathrm{m}^{-1}$, respectively. These results refer to the importance of $\mathrm{N}$ fertilization to quinoa crop grown in saline environments and the higher rate of applied $\mathrm{N}$ not only enhance the yield under salinity stress but also improve the defense mechanism against salinity through enhancing the $\mathrm{K}: \mathrm{Na}$ ratio (Fig. 3). In contrast to findings reported by Mujica et al. (2001) who stated that quinoa needs no potassium fertilization. The current results suggests that application of $\mathrm{K}$ fertilizer to the crop grown in saline environments may enhance the crop yield and there is a need to further studies related to the influence of $\mathrm{K}$ fertilization rates on crop yield and quality.

\section{Quality of quinoa hay as a ruminant feed:}

Digestibility is the most common nutritive parameter used in feeding standards for ruminants and is the basal unit when evaluating the nutritive value of forage (Tassone et al., 2014). Proximate analyses of quinoa hay under salinity stress and different levels of $\mathrm{N}$ fertilization are given in Table (3). The results revealed that the quinoa hay under different rates of $\mathrm{N}$ fertilization and salinity did not differ in organic matter (OM) content but contain an acceptable range (84.08 $87.96 \%$ ) when compared to clover hay. Feed protein content is often considered a good determinant of quality and crude protein $(\mathrm{CP})$ content is very different across feeds, but within a feed, higher protein is usually associated with higher quality. Referring to clover hay's $\mathrm{CP}$, the harvested hay of quinoa irrigated by fresh and $10 \mathrm{dS} \mathrm{m}^{-1}$ water and fertilized by $28.56 \mathrm{~g} \mathrm{~N} \mathrm{~m}^{-2}(\mathrm{~N} 2)$ gave CP 19 and $18.8 \%$, respectively (Table 3 ) and reflected good quality with respect to protein content. Quinoa hay had lower ether extract (EE) or crude fat content at the control and treated plant compared to the clover hay. The low values of EE listed in Table $3(0.14$ $-0.67 \%$ ) indicate that quinoa hay is considered a poor source for energy where the optimum range is $2-2.8 \%$
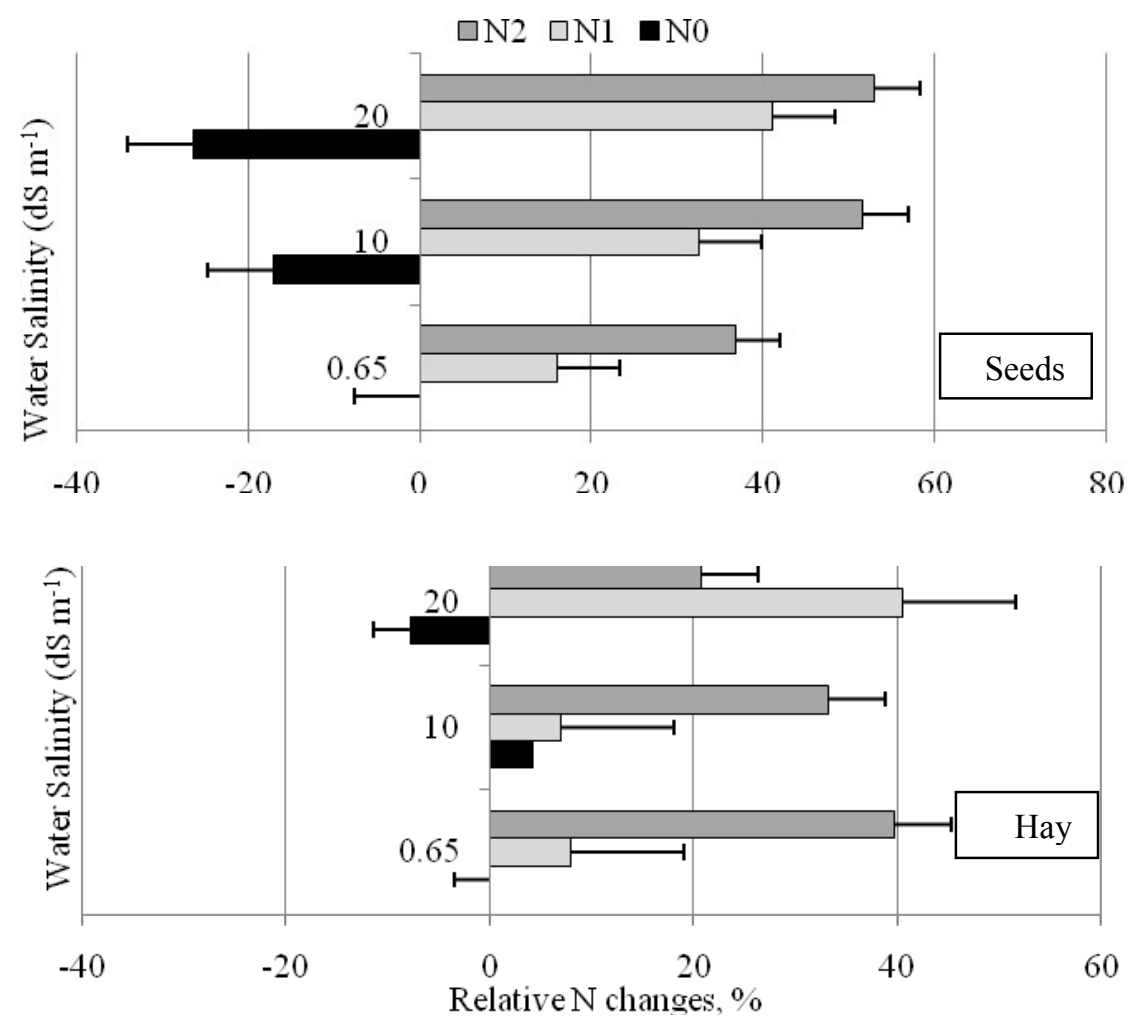

Fig.2. The relative change of nitrogen content in seeds and hay of Regalona quinoa cultivar as results of nitrogen application rate and salinity of irrigation water 


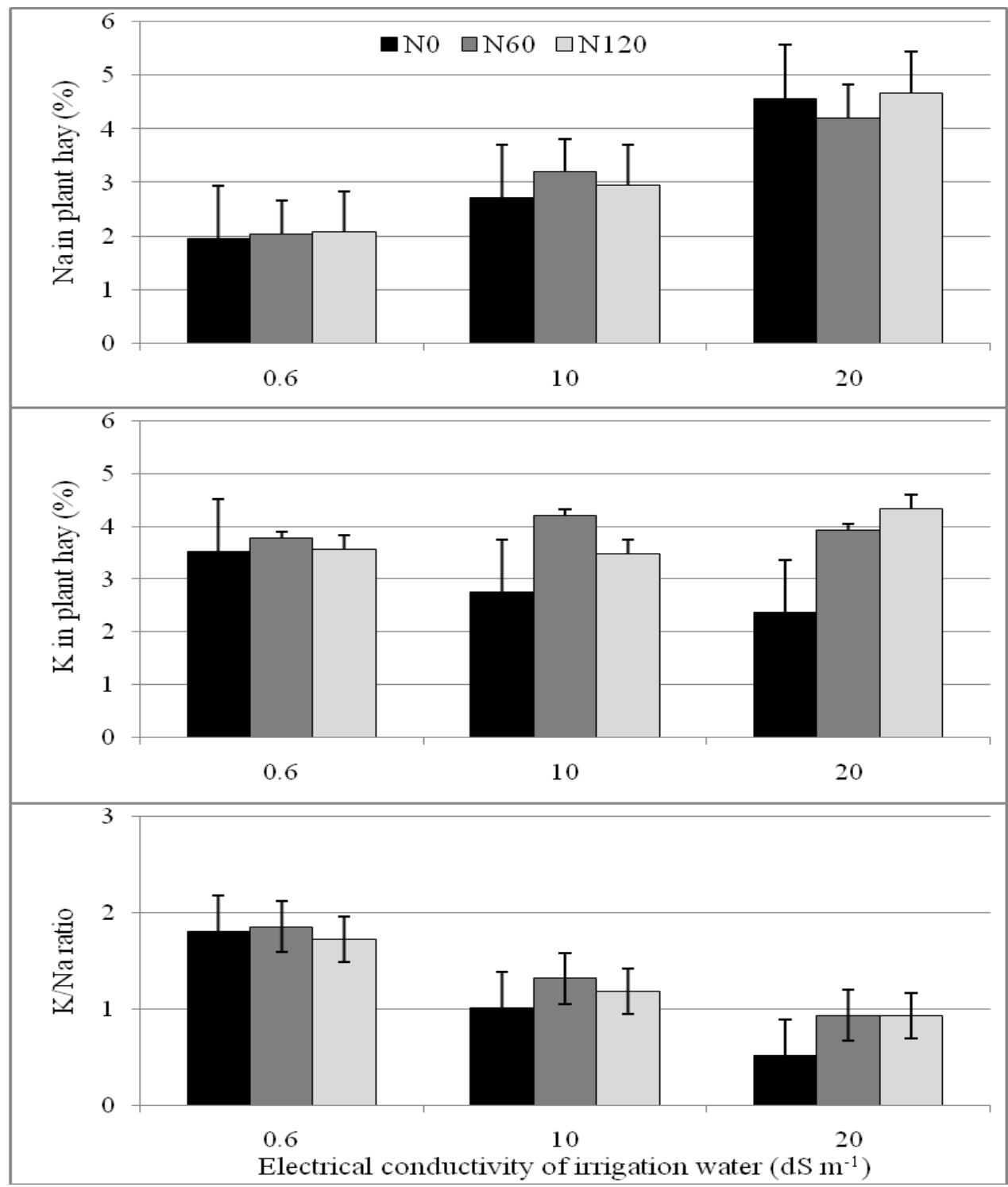

Fig.3. Sodium, potassium and potassium:sodium ratio in the dry matter of quinoa hay as a result of nitrogen fertilization rate and salinity of irrigation wate

Table 3. Proximate analyses (on DM basis) of quinoa hay of Regalona cultivar compared to clover hay for testing as forage for ruminants

\begin{tabular}{|c|c|c|c|c|c|c|c|c|c|c|}
\hline \multirow{4}{*}{ Items (\%) } & \multirow{4}{*}{$\begin{array}{c}\text { Clover } \\
\text { Hay }\end{array}$} & \multicolumn{9}{|c|}{ Quinoa } \\
\hline & & \multicolumn{9}{|c|}{ Water Salinity (dS/m) } \\
\hline & & \multicolumn{3}{|c|}{$E C=0.65$} & \multicolumn{3}{|c|}{$\mathrm{EC}=10$} & \multicolumn{3}{|c|}{$E C=20$} \\
\hline & & No & N1 & $\mathrm{N} 2$ & N0 & N1 & $\mathrm{N} 2$ & No & N1 & $\mathrm{N} 2$ \\
\hline $\mathrm{OM}$ & 84.9 & 88.0 & 86.6 & 84.2 & 86.5 & 87.0 & 86.9 & 87.1 & 84.3 & 84.1 \\
\hline $\mathrm{CP}$ & 15.5 & 13.8 & 14.4 & 19.0 & 14.0 & 14.9 & 18.8 & 12.4 & 17.6 & 14.5 \\
\hline EE & 2.5 & 0.87 & 0.79 & 0.27 & 0.14 & 0.22 & 0.32 & 0.35 & 0.48 & 0.36 \\
\hline NDF & 49.8 & 65.0 & 57.5 & 54.9 & 58.7 & 59.9 & 61.0 & 60.5 & 55.9 & 51.0 \\
\hline $\mathrm{ADF}$ & 32.5 & 41.1 & 34.2 & 31.1 & 33.0 & 36.1 & 38.3 & 37.0 & 32.8 & 29.1 \\
\hline ADL & 7.3 & 8.4 & 7.5 & 6.8 & 7.1 & 7.5 & 8.2 & 6.8 & 7.0 & 6.3 \\
\hline Hemicellulose & 17.3 & 23.9 & 23.3 & 23.8 & 25.7 & 23.8 & 22.7 & 23.5 & 23.1 & 21.9 \\
\hline Cellulose & 25.2 & 32.7 & 26.8 & 24.4 & 25.8 & 28.6 & 30.1 & 30.2 & 25.8 & 22.8 \\
\hline
\end{tabular}


(Shewmaker et al., 2009). With respect to fiber consideration in the ruminant feed, Neutral detergent fiber (NDF) content of quinoa hay was higher at all levels of $\mathrm{N}$ fertilization and water salinity (51.0 $61.0 \%$ ) comparing to clover hay. Shewmaker et al. (2009) denoted that NDF values increased with maturity or with increasing plant composition and high NDF values are related to decline in animal intake. Quinoa hay under different conditions of $\mathrm{N}$ fertilization and water salinity did not differ in acid detergent fiber (ADF) content. Hemicellulose is high at all conditions of fertilization and salinity compared to the clover hay, whereas cellulose content was higher in N0- treated plants and irrigated by 0.65 and $20 \mathrm{dS} \mathrm{m}^{-1}$ water and in plants fertilized by $\mathrm{N} 1$ and irrigated by $10 \mathrm{dS} \mathrm{m}^{-1}$ water.

\section{CONCLUSIONS}

The results of the current investigation showed the importance of nitrogen fertilizer application to quinoa crops grown in saline environments to reach the maximum or optimum yield. The high rate of applied $\mathrm{N}$ fertilizer $\left(28.56 \mathrm{~g} \mathrm{~N} / \mathrm{m}^{2}\right)$ was effective in obtaining high yield under the irrigation with water of $20 \mathrm{dS} / \mathrm{m}$. Further studies are needed to clarify the role of nitrogen fertilizer and also $\mathrm{K}$ and $\mathrm{P}$ applications for optimizing quinoa production in marginal soils under the Mediterranean climate. The study indicated the importance of quinoa hay as forage supplement for ruminant due to its high content in both organic matter and crude protein.

\section{REFERENCES}

Abdel Kawy, W.A.M. and R.R. Ali. 2012. Assessment of soil degradation and resilience at northeast Nile Delta, Egypt: The impact on soil productivity. The Egypt. J. Remote Sensing and Space Sci. 15 (1): 19-30.

Ahmed, I. M., U. A. Nadira, G. P. Zhang and F. B. Wu. 2016. Drought Tolerant Wild Species Are the Important Sources of Genes and Molecular Mechanisms Studies: Implication for Developing Drought Tolerant Crops. in: Drought Stress Tolerance in Plants, 1: 401-426.

AOAC, 1990. Official Methods of Analysis, fourteenth ed. Association of Official Analytical Chemists, Washington, DC.

Arendt, E. K. and E. Zannini. 2013. Cereal grains for the food and beverage industries. Woodhead Publishing Series in Food Science, Technology and Nutrition: No. 248: 409438.

Bazile, D., D. Bertero, and C. Nieto. 2015. State of the Art Report on Quinoa around the World in 2013. Rome: Food and Agriculture Organization of the United Nations (FAO) $\&$ CIRAD (Centrede cooperation internationale en recherché agronomique pour le développement).
El-Ramady, H.R., S. M. El-Marsafawy, and L. N. Lewis. 2013. Sustainable Agriculture and Climate Changes in Egypt. Sustain. Agric. Rev., 12: 41- 96.

Galvani, A. 2007. The challenge of the food sufficiency through salt tolerant crops. Rev. Environ. Sci. Biotechnol., $6: 3-16$.

González, J. A., S.S.S. Eisa, S.A.E.S. Hussin and F.E. Prado. 2015. Quinoa: an Incan crop to face global changes in agriculture, in K. M. Murphy and J. Matanguihan (Eds.) "Quinoa: Improvement and Sustainable Production", Hoboken, NJ: John Wiley \& Sons, pp 7-11.

Hiernaux, P., C. Dardel and L. Kergoat. 2016. Desertification, Adaptation and Resilience in the Sahel: Lessons from Long Term Monitoring of Agro-ecosystems. in: The End of Desertification. Series of Springer Earth System Sciences pp 147-178.

Jacobsen, E.E., B. Skadhauge and S.-E. Jacobsen. 1997. Effect of dietary inclusion of quinoa on broiler growth performance. Animal Feed Sci. Technol., 65: 5-14.

Jonse, J.B. and V.W. Case. 1990. Sampling, Handling and Analyzing Plant Tissue Samples. In R.L. Westerman (Ed.) "Soil Testing and Plant analysis". $3^{\text {rd }}$ Ed. SSSA Book Series no 3. Madison, Wi., USA.

Karamesouti, M., V. Detsis, A. Kounalaki, P. Vasiliou, L. Salvati and C. Kosmas. 2015. Land-use and land degradation processes affecting soil resources: Evidence from a traditional Mediterranean cropland (Greece). Catena, 32: 45-55.

Kubelkov, P., D. Jal, P. Homolka and B. Cerm ak. 2013. Effect of dietary supplementation with treated amaranth seeds on fermentation parameters in an artificial rumen. Czech J. Animal Sci. 58, 159-166.

Livingston, A. D. 2013. The Whole Grain Cookbook: Wheat, Barley, Oats, Rye, Amaranth, Spelt, Corn, Millet, Quinoa, and More (Second Ed.). Lyons Press. USA, pp: 11-18.

Mahmoud, A.H. 2017. Production of Quinoa (Chenopodium quinoa) in the Marginal Environments of South Mediterranean Region: Nile Delta, Egypt. Egypt. J. Soil Sci. (In press).

Malhotra, K. and G.K. Chhabra 2013. Drought and Salinity Tolerant Biofuel Crops for the Thar Desert. in Plant Acclimation to Environmental Stress. Springer, Netherlands. pp: 74-81.

Mujica, A., J. Izquierdo, and J. P. Marathee, 2001. Origen y descripcion de la quinua. In: A. Mujica, S.-E. Jacobsen, J. Izquierdo, and J. P. Marathee, eds. Quinua (Chenopodium quinoa Willd.) - Ancestral cultivo andino, alimento del presente y futuro, pp. 9-29. FAO, UNA-Puno, CIP, Santiago.

Razzaghi, F., F. Plauborg, S.E. Jacobsen, C. R. Jensen, M. N. Andersen. 2012. Effect of nitrogen and water availability of three soil types on yield, radiation use efficiency and evapotranspiration in field-grown quinoa. Agric. Water Manag. 109: 20-29. 
Robinson, T.F., B.W. Harris and N.P. Johnston. 2013a. Initial compartment $1 \mathrm{pH}$ response to grain supplementation in alpacas (Vicugna pacos) fed alfalfa and grass hay. J Animal Sci. Adv. 3: 354-360.

Robinson, T.F., B.L. Roeder and N.P. Johnston. $2013 \mathrm{~b}$. Nitrogen balance and blood metabolites of llama (Lama Glama) fed barley hay supplemented with alfalfa and quinoa straw in Bolivia. J. Animal Sci. Adv. 3: 386-391.

Romo-Leon, J.R. and W. J. D. van Leeuwen. 2016. Land Use and Environmental Variability Impacts on the Phenology of Arid Agro-Ecosystems. Environ. Manag. 57 (2): 283297.

Ruiz, K.B., S. Biondi, R. Oses, I. S. Acuña-Rodríguez, F. Antognoni, E. A. Martinez-Mosqueira, A. Coulibaly, A. Canahua-Murillo, M. Pinto, A. Zurita-Silva, D. Bazile, S. E. Jacobsen and M. A. Molina-Montenegro. 2014. Quinoa biodiversity and sustainability for food security under climate change. A review. Agron. Sust. Develop., 34 (2): $349-359$.

Rosero, O.L., D.A. Rosero D. Luke_sov. 2010. Determination of the capacities of farmers to adopt quinoa grain (Chenopodium quinoa willd.) as potential feedstuff. Agricultura Tropica et Subtropica 43: 308-315.

Schulte auf'm Erley, G., H. P. Kaul.,M. Kruse, and W. Aufhammer. 2005. Yield and nitrogen utilization efficiency of the pseudocereals amaranth, quinoa, and buckwheatunder differing nitrogen fertilization. Europ. J. Agron. 22: 95-100.

Scanlin, L. and K.A. Lewis. 2017. Quinoa as a Sustainable Protein Source: Production, Nutrition, and Processing. In: S. R. Nadathur et al., (Eds.) "Sustainable Protein Sources". Elsevier Inc., pp223-238.

Shams, A. 2011. Combat Degradation in Rain Fed Areas by Introducing New Drought Tolerant Crops in Egypt. Intern. J. Water Res. Arid Environ. 1(5): 318-325.
Shams, A. 2015. Final Report about Quinoa Production and Research in Egypt. Regional Project of Quinoa (TCP/RAB/3403). Food Agric. Organization.

Shams, A.S. (2012) Response of quinoa to nitrogen fertilizer rates under sandy soil conditions. In: Proceedings of the 13th International Agronomy Conference, Faculty of Agriculture, Benha University, Egypt, 9-10 September 2012, pp. 195-205.

Shewmaker, G.E., M. Chahine and R. Wilson. 2009. Parameters for good quality alfalfa hay. In: Proceedings, Idaho Alfalfa and Forage conference. Fab. 3-4, 2009. ID. USA.

Spehar C.R. and R.L. de Barros Santos. 2005. Agronomic performance of quinoa selected in the Brazilian Savannah. Pesq. agropec. bras., Brasilia, 40 (6): 609-612.

Szilagyi, L. and B. Jornsgard. 2014. Preliminary agronomic evaluation of henopodium quinoa Willd. under climatic conditions of Romania. Scientific Papers. Series A. Agron.,LVII: 339-343.

Tassone, S., G. Masoero and P.G. Peiretti. 2014. Vibrational spectroscopy to predict in vitro digestibility and the maturity index of different forage crops during the growing cycle and after freeze- or oven-drying treatment. Animal Feed Sci. Technol. 194: 12-25.

Tokatlidis, I.S. 2013. Adapting Maize Crop to Diverse AgroEcosystems. Sustain. Agric. Rev., 12: 97-117.

Tomaz, C., C. Alegria, J. M. Monteiro and M. C. Teixeira. 2013. Land cover change and afforestation of marginal and abandoned agricultural land: A 10 year analysis in a Mediterranean region. Forest Ecol. Manag., 308: 40-49.

Van Soest, P.J., J.B. Robertson and B.A. Lewis. 1991. Methods for dietary neutral detergent fiber, and non starch polysaccharides in relation to animal nutrition. J. Dairy Sci. 74, 3583-3597.

Wu G, A.J. Peterson, C.F. Morris and K.M. Murphy. 2016. Quinoa Seed Quality Response to Sodium Chloride and Sodium Sulfate Salinity. Front. Plant Sci., 7:790 (1-8). 


\section{الملخص العربي \\ استجابة نبات الكينوا للنيتروجين والرى بالمياه الملحية \\ أمل حسن محمود، صبحى محمد سلام}

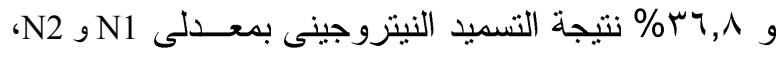
على التو الى، عن محتو اهما فى الكينوا غير المسمدة. بينما

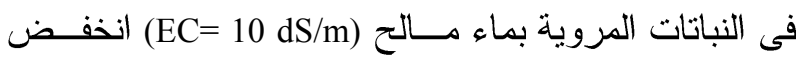

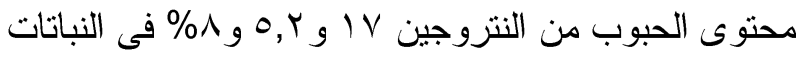
المسمدة ب N0 و N1 و N2، على التو اللى، مقارنة بالمرويـــة بماء عذب. وكان الانخفاض أكبر في تللك المرويــة بمـــاء

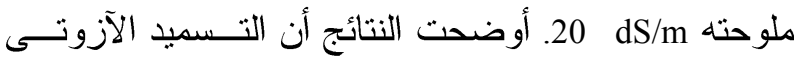

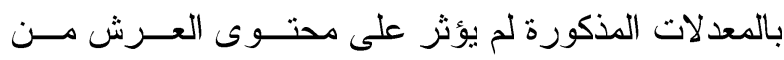

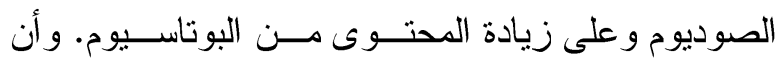
استخدام عرش الكينو ا كعلف للماثية تم تدعيمه من خــلال ارتفاع محتوى العرش من المادة العضوية و البروتين مقارنة بعرش البرسيم بينما انخفاض قيم مستخلص الايثر وارتفاع

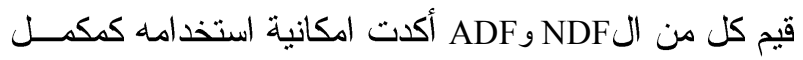
غذائى فى العلف.
تم در اسة استجابة نباتات الكينـــوا (صــنف ريجالونــا) النامية فى أرض طينية تحت ظروف من الاجهاد الملحـى لئى

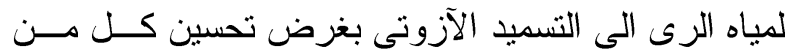

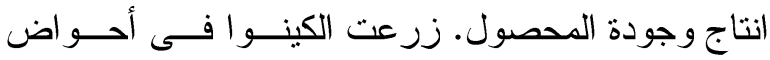
الليسيمترات وتم اختبار تأثير اضافة النيتروجين بمعـدلات

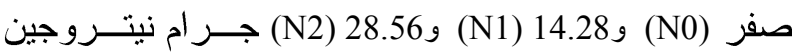

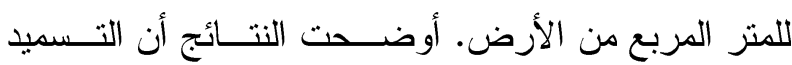

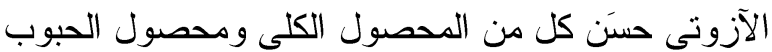

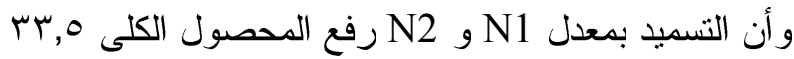
و • ، و وق المحصول غير المسمد (N0) عند الرى بماء

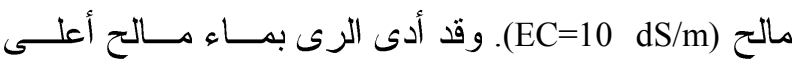
\% الى زيادة المحصول الكـــ (EC=20 dS/m) المسمد بالمعدلات المذكورة. وقد لوحظ فى النباتات المروية بماء عذب أن محتوى النتروجين فى عــرش الكينــــواز اد اد

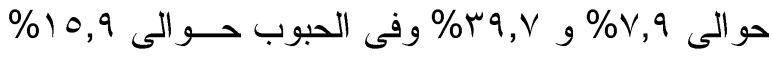

